\title{
SEPARATION OF ISOPROPYLBENZENE FROM A MID- CONTINENT PETROLEUM BY ADSORPTION WITH SILICA GEL AND DISTILLATION WITH ACETIC ACID ${ }^{1}$
}

\author{
By Joseph D. White, ${ }^{2}$ and Frank W. Rose, Jr. ${ }^{2 a}$
}

\section{ABSTRACT}

Isopropylbenzene was isolated from the gasoline distillate of a midcontinent petroleum, which boiled between $144^{\circ}$ and $154^{\circ} \mathrm{C}$, and in which the concentration of the compound was about 3 percent. By adsorbing the aromatic portion of the distillate on silica gel and distilling the adsorbed material with glacial acetic acid, an aromatic concentrate was obtained which, by subsequent fractional distillation, yielded nearly pure isopropylbenzene. The physical properties of the isolated material were: $\mathrm{bp}_{760}, 152.39^{\circ} \mathrm{C} ; \mathrm{fp},-96.46^{\circ} \mathrm{C} ; d_{4}^{20}, 0.8634 ; n_{D}^{20}, 1.4914$; mole percent purity, 98.4 ; compared with bp $760,152.38^{\circ} \mathrm{C}$; fp, $-96.25^{\circ} \mathrm{C}$; $d_{4}^{20}, 0.8633 ; n_{D}^{20}, 1.4915$ for a synthetic sample with a calculated purity of 99.8 mole percent. The amount by volume of isopropylbenzene in the petroleum is estimated to be about 0.03 of the amount of the previously isolated $n$-nonane. On this basis, the isopropylbenzene constitutes approximately 0.03 percent of the petroleum.

Data are given for the azeotropic distillation with acetic acid of a mixture containing 20 percent of isopropylbenzene and 80 percent of $n$-nonane. Distillation of the aromatic concentrate from the petroleum fraction also gave evidence for the presence of $n$-propylbenzene. Properties of the residual portion of the petroleum fraction indicate that it is chiefly composed of naphthenic hydrocarbons.

\section{CONTENTS}

Page

II. Previous treatment of the fraction and indications of the presence of aromatic constituents__._.

III. Adsorption of aromatic constituents with silica gel

IV. Preliminary separation of the aromatic components from the adsorbed material by extraction _............ 156

V. Distillation of the adsorbed material with acetic acid ....... 157

VI. Further fractionation and analysis of the material filtered through silica gel . . . . . 160

VII. Isolation and properties of isopropylbenzene

VIII. Content of isopropylbenzene in the petroleum

IX. References .......... 164

\section{INTRODUCTION}

Isopropylbenzene (cumene) was one of the first compounds to be to be found in petroleum [1]. ${ }^{3}$ Later investigations [2] have shown that this compound constitutes, to a greater or lesser extent, a portion of the petroleum from all parts of the world. Usually, its presence

1 Financial assistance has been received from the research fund of the American Petroleum Institute. This work is part of Project 6, The Separation, Identification, and Determination of the Constituents of Petroleum.

2 Formerly Research Associate at the National Bureau of Standards, representing the American Petroleum Institute.

2a Research Associate at the National Bureau of Standards, representing the American Petroleum Institute.

3 Figures in brackets indicate the literature references at the end of this paper. 
has been detected by means of chemical derivatives, e. g., the halides, sulfonic acids, nitrocompounds, or oxidation products, obtained by treating a specific fraction obtained by distillation with the appropriate reagent. The detection of isopropylbenzene is an important contribution, in itself, to the knowledge of petroleum. However, in the analysis of gasoline by isolating and identifying the individual component hydrocarbons, the removal of an aromatic constituent is an expedient step to the subsequent analysis of the paraffin and naphthene hydrocarbons which are associated with it in the same distillate. A few years ago, Mulany and Watson [3], by sulfonating and hydrolyzing a kerosene fraction of Burma petroleum, obtained an aromatic product of which one of the constituents was isopropylbenzene. Isopropylbenzene does not sulfonate readily in the low concentrations in which it exists in petroleum fractions, and vigorous treatment with fuming sulfuric acid is necessary in order to remove it. This method is too harsh to use where it is necessary to guard against decomposing other constituents which must be left structurally intact.

The present problem was to remove the small portion of aromatic material (about 3 percent) from a large fraction of petroleum, and to separate it into its components. This was done satisfactorily by adsorbing the aromatic compounds, together with some of the aliphatic hydrocarbons, on silica gel and concentrating the aromatic portion further by distilling the adsorbed material with an azeotropic agent, acetic acid. Isopropylbenzene was then obtained from the concentrate by fractional distillation.

\section{PREVIOUS TREATMENT OF THE FRACTION AND INDICATIONS OF THE PRESENCE OF AROMATIC CON- STITUENTS}

The naphtha fraction from 2,250 liters of an Oklahoma petroleum, ${ }^{4}$ when systematically distilled in the manner described in an earlier paper [4], yielded 73 liters which boiled between $144^{\circ}$ and $160^{\circ} \mathrm{C}$ (graph I, fig. 1). After extracting the xylenes from the material which boiled below $144^{\circ} \mathrm{C}$ [5], the residual oil, together with the fractions shown in graph I, was redistilled to yield the fractions shown in graph II. The fractions containing the isopropylbenzene boiled between $144^{\circ}$ and $152^{\circ} \mathrm{C}$ and had a combined volume of 44 liters. From those which boiled between $146^{\circ}$ and $151^{\circ} \mathrm{C}, 10$ liters of $n$-nonane was separated by a system of alternating crystallization and distillation [4]. ${ }^{5}$ Following the removal of xylenes and $n$-nonane, the remainder of the material boiling between $130^{\circ}$ and $160^{\circ} \mathrm{C}$ was redistilled to realign it with respect to boiling point. The distillation was conducted at a pressure of $215 \mathrm{~mm} \mathrm{Hg}$ to minimize the possibility of decomposing the oil. The volumes and refractive indices of the halfdegree fractions, which distilled between $102^{\circ}$ and $110.5^{\circ} \mathrm{C}$, are shown

\footnotetext{
4 A description of the oil is given in BS J. Research 2, 469, table 1 (1929) RP45, and J. Research NBS 15, 212 (1935) RP824.

5 In the paper describing the isolation of $n$-nonane [4], a distillation curve is given on p. 908 which, erroneously, was used to indicate the original distillate. Actually, the curve represents the remaining protion of the distillate after extracting the fractions, $141^{\circ}$ to $144^{\circ} \mathrm{C}$, and after removing a 4.5 -liter fraction of $n$-nonane from the material boiling between $146^{\circ}$ and $151^{\circ} \mathrm{C}$. On the same page of the paper, a typographical error occurs in which the volume of petroleum originally distilling between $130^{\circ}$ and $160^{\circ} \mathrm{C}$ was reported to be "175 liters" instead of 125 liters.
} 
in figure 2. In all, 31 liters was obtained. The normal boiling points of the fractions ranged from $144.6^{\circ}$ to $153.6^{\circ} \mathrm{C}$. All of the fractions between $102^{\circ}$ and $106^{\circ} \mathrm{C}\left(\mathrm{bp}_{760}, 144.6^{\circ}\right.$ and $\left.149.0^{\circ} \mathrm{C}\right)$ were characterized by an odor which suggested that of certain essential oils, and which was later found to be associated with the presence of isopro-

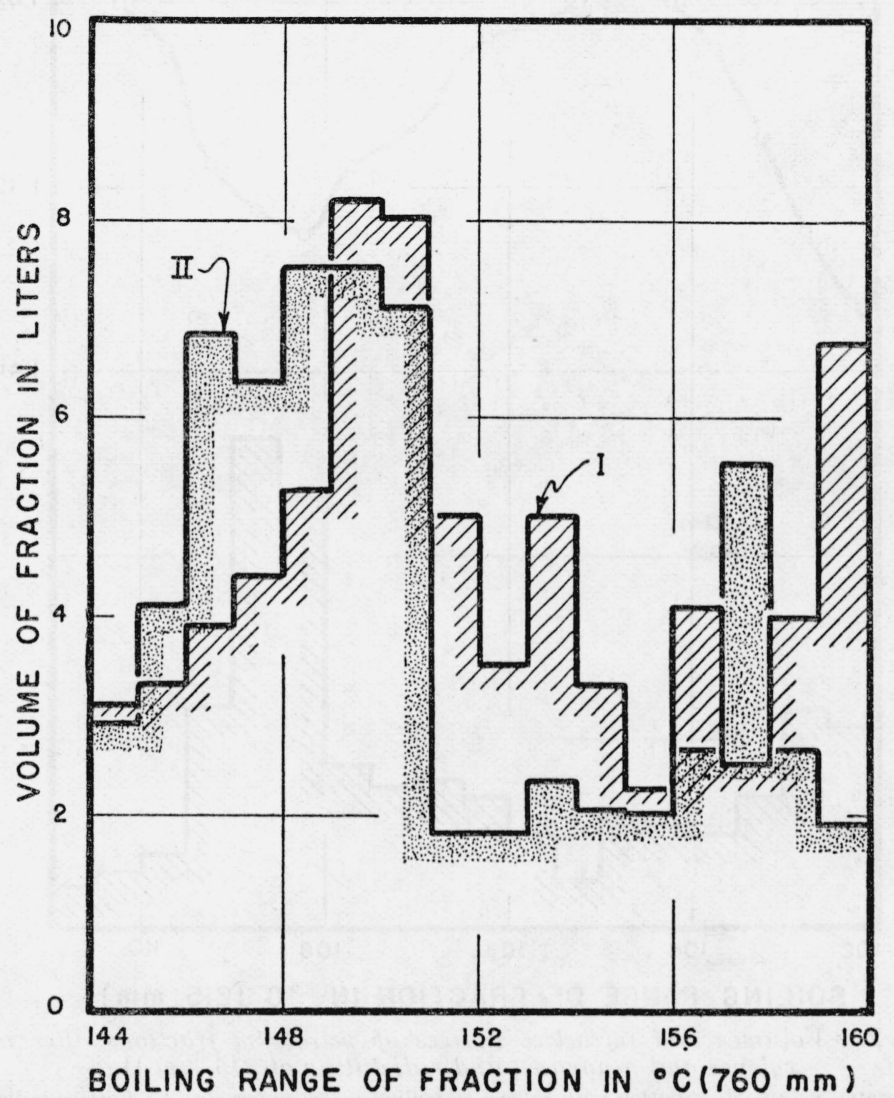

FIGURe 1.-Volume distribution of the petroleum distillate boiling between $144^{\circ}$ and $160^{\circ} \mathrm{C}$.

Graph I, volumes of successive 1-degree cuts of the original distillate. Graph II, volumes after extracting xylenes from the material boiling below $144^{\circ} \mathrm{C}$ and redistilling the residual oil together with the fractions shown in graph I.

pylbenzene. The change in refractive index, upon treating representative fractions with a mixture of nitric and sulfuric acid, indicated that the distillate contained, on the whole, about 3 percent by volume of aromatic constituents. The bulk of the distillate was composed of a mixture of paraffin and naphthene hydrocarbons, as judged by the refractive index of the oil after treatment with the nitrating mixture. The results of the test are shown in table 1. 


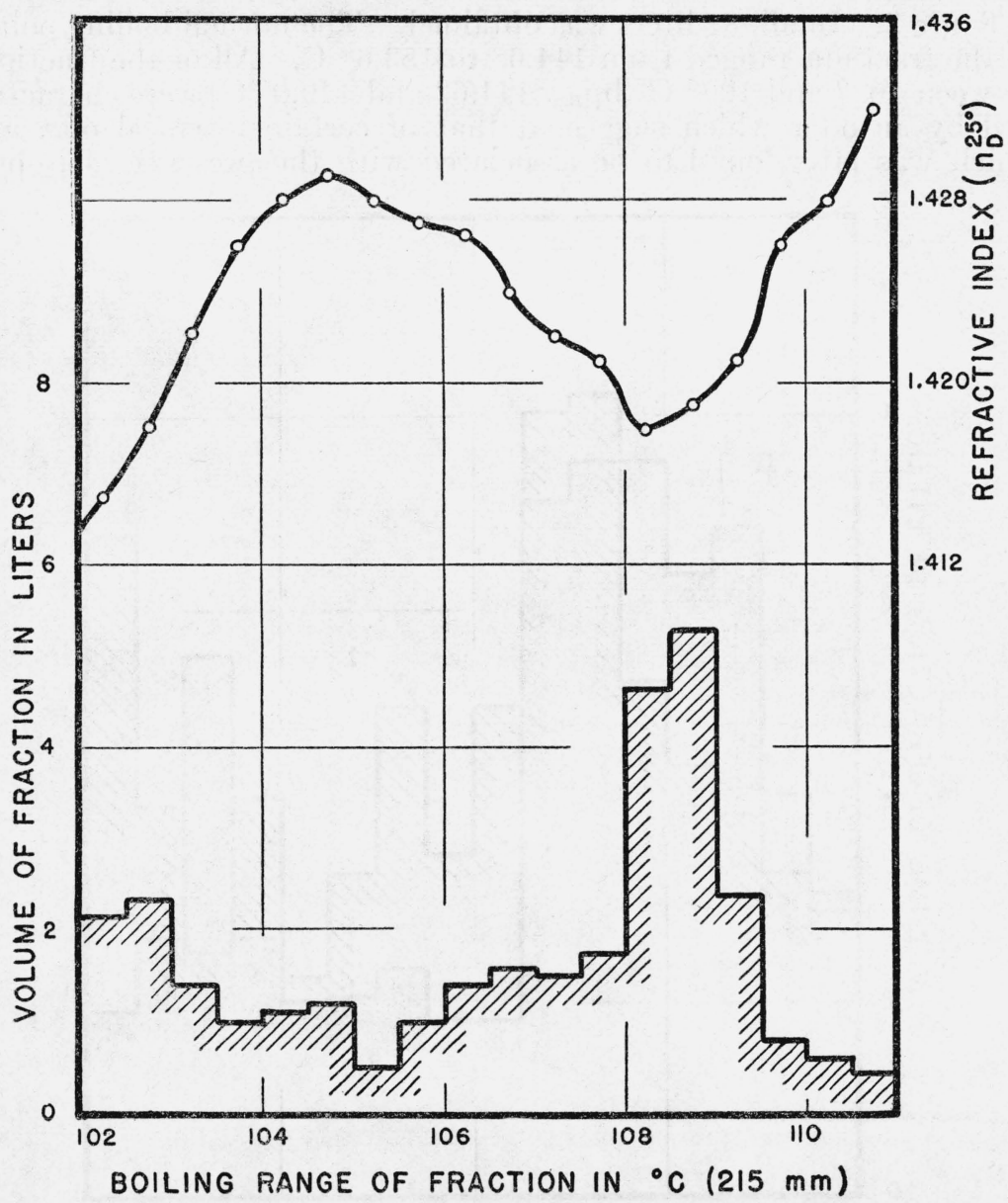

FIgURE 2.-Volumes and refractive indices of petroleum fractions after removing xylenes and $n$-nonane, and redistilling at $215 \mathrm{~mm} \mathrm{Hg}$.

Lower graph, volume distribution with respect to boiling range; upper curve, refractive indices of successive half-degree cuts.

TABLE 1.-Percentage of aromatic constituents in selected distillation fractions as indicated by their change in refractive index upon nitration

\begin{tabular}{|c|c|c|c|c|}
\hline \multirow{2}{*}{ Fraction boiling range $215 \mathrm{~mm} \mathrm{Hg}$} & \multirow{2}{*}{ Volume } & \multicolumn{2}{|c|}{ Refractive index } & \multirow{2}{*}{$\begin{array}{l}\text { Estimated } \\
\text { mole per- } \\
\text { centage of } \\
\text { aromatics } 1\end{array}$} \\
\hline & & $\begin{array}{c}\text { Before } \\
\text { nitration }\end{array}$ & $\underset{\text { nitration }}{\text { After }}$ & \\
\hline $\begin{array}{l}{ }^{\circ} \mathrm{C} \\
102.5 \text { to } 103.0 \\
104.5 \text { to } 105.0 \\
108.5 \text { to } 109.0\end{array}$ & $\begin{array}{l}m l \\
2,150 \\
1,200 \\
5,300\end{array}$ & $\begin{array}{r}n_{D}^{25} \\
1.418_{1} \\
1.429_{2} \\
1.418_{7}\end{array}$ & $\begin{array}{r}n_{D}^{25} \\
1.416_{3} \\
1.425_{4} \\
1.416_{7}\end{array}$ & $\begin{array}{l}2.5 \\
6.1 \\
3.3\end{array}$ \\
\hline
\end{tabular}

1 Assuming $n_{D}^{25}=1.488_{0}$ for aromatics. 


\section{ADSORPTION OF AROMATIC CONSTITUENTS WITH SILICA GEL}

Methods were considered for separating small amounts of aromatic material from hydrocarbon solutions. Previously, liquid sulfur dioxide had been used to extract the "xylene fraction" of the petroleum [5] which contained about 25 mole percent of aromatic constituents. This method, no doubt, could be satisfactorily applied to 3-percent solutions, provided an efficient extraction column were used. However, reports on the fractionation of petroleum by adsorption with silica gel [6] prompted a preliminary study which indicated that adsorption would be a more satisfactory way to remove aromatic constituents from dilute solutions. Experiments with mixtures of $p$-xylene in $n$-nonane showed that gel of 40 to 200 mesh, obtained from the Silica Gel Corporation, in Baltimore, adsorbed effectively the aromatic constituent, permitted rapid filtration, and retained only a relatively small amount of unadsorbed oil. The capacity of the gel was such that a 100-g sample adsorbed 10 " $\mathrm{ml}$ of $p$-xylene from a 5percent solution, the capacity varying somewhat with the concentration of aromatics in the solution being filtered. As an outcome of these experiments, a method was developed for separating petroleum fractions with silica gel, and was used to remove the aromatic constituents from the petroleum distillate indicated in figure $2 .{ }^{6}$

The distillate was treated with silica gel as follows: Fractions with narrow boiling ranges, and with approximately the same concentration of aromatic material, were filtered through Pyrex tubes, each containing about $400 \mathrm{~g}$ of gel. This quantity of gel was sufficient to remove the aromatic constituents from 1 liter of a 4-percent solution. Complete removal of the highly refractive aromatic hydrocarbons was judged partly by noting that the lowered refractive index of the filtered oil matched that of a sample which had been freed from aromatic material by nitration, and partly by refiltering the oil through fresh gel and noting that its refractive index remained virtually unchanged. The portions of filtrate having these properties were stored as being free of aromatics. As more and more of the distillate filtered through a given column of gel, the refractive index of the filtrate, which was tested at intervals, eventually began to rise towards that of the oil being filtered. At this point the gel was nearly saturated. The column was then allowed to drain, after which a large portion of the oil adhering to the gel by surface tension was displaced downward by adding distilled water at the top of the column. The sharpness with which the adhering oil could be displaced by this action of the water depended on the diameter of the filtering tube. At first, in order to hasten the filtering process, tubes were used which held columns of gel $8 \mathrm{~cm}$ in diameter and $25 \mathrm{~cm}$ high. These were soon rejected because channeling of the gel necessitated extra filtering of the oil, and also resulted in unsatisfactory separation of the oil adhering to the gel from that which was adsorbed. Later, tubes were used which held the same amount of gel, but which measured 2 by $200 \mathrm{~cm}$. When well drained, these columns retained approximately $170 \mathrm{ml}$ of oil, of which $100 \mathrm{ml}$ of the adhering portion could be displaced with water. After this displacement, the gel was flushed from the tube with a

${ }^{6}$ Later, an extended study of the separation of synthetic mixtures of hydrocarbons with silica gel was made by B.J. Mair and one of the authors, A detailed account of this study has already been published [7]. 
stream of water delivered under pressure, and the adsorbed portion of the oil was recovered by gently distilling the gel suspension with steam. The wet gel was reactivated by transferring it to a Pyrex tube, sucking it as dry as possible, and then heating it in an oven for 24 hours at a temperature of $300^{\circ}$ to $350^{\circ} \mathrm{C}$ while air was drawn through it.

Table 2 shows the data for the filtration of the petroleum distillate. The loss by volume in the process was 2 percent. By this method the aromatic material was completely separated from the distillate and concentrated into a fraction whose volume was less than a tenth of that of the original. However, the aromatic constituents comprised only a third of the adsorbed fraction, a condition resulting not only from the imperfect separation of adhering oil from the adsorbed portion, but also from the nature and composition of the liquid being filtered. The remainder of the adsorbed material consisted mainly of naphthene hydrocarbons, but it also contained some gum which had formed in the distillate during the 3 years it had been stored prior to filtration.

TABLE 2.-Volumes and refractive indices of the distillation fractions before and after filtering through silica gel

\begin{tabular}{|c|c|c|c|c|c|c|c|}
\hline \multirow{3}{*}{$\begin{array}{c}\text { Boiling range at } 215 \mathrm{~mm} \mathrm{Hg} \\
\text { before filtering }\end{array}$} & \multicolumn{4}{|c|}{ Volume } & \multicolumn{3}{|c|}{ Refractive index } \\
\hline & \multirow{2}{*}{$\begin{array}{l}\text { Before } \\
\text { filtering }\end{array}$} & \multicolumn{2}{|c|}{ After filtering } & \multirow{2}{*}{$\begin{array}{l}\text { Lost in } \\
\text { the pro- } \\
\text { cedure }\end{array}$} & \multirow{2}{*}{$\begin{array}{l}\text { Before } \\
\text { filtering }\end{array}$} & \multicolumn{2}{|c|}{ After filtering } \\
\hline & & Filtrate & Adsorbed & & & Filtrate & Adsorbed \\
\hline $\begin{array}{l}102.0 \text { to } 103.5 \\
103.5 \text { to } 106.0 \\
106.0 \text { to } 107.0 \\
107.0 \text { to } 108.0 \\
108.0 \text { to } 108.5 \\
108.5 \text { to } 109.0 \\
109.0 \text { to } 109.5 \\
109.5 \text { to } 110.5\end{array}$ & $\begin{array}{l}m l \\
5,660 \\
4,735 \\
2,890 \\
3,215 \\
4,565 \\
5,035 \\
2,515 \\
1,465\end{array}$ & $\begin{array}{l}m l \\
5,150 \\
3,905 \\
2,535 \\
2,870 \\
4,140 \\
4,585 \\
2,305 \\
1,210\end{array}$ & $\begin{array}{c}m l \\
460 \\
750 \\
260 \\
280 \\
320 \\
320 \\
180 \\
215\end{array}$ & $\begin{array}{r}m l \\
50 \\
80 \\
95 \\
65 \\
105 \\
130 \\
30 \\
40\end{array}$ & $\begin{array}{l}n_{D}^{25} \\
\text { 1. } 4181 \\
1.4288 \\
1.4255 \\
1.4215 \\
1.4188 \\
1.4187 \\
1.4202 \\
1.4270\end{array}$ & $\begin{array}{l}n_{D}^{25} \\
\text { 1. } 4160 \\
1.4245 \\
1.4230 \\
1.4200 \\
1.4173 \\
1.4168 \\
1.4172 \\
1.4222\end{array}$ & $\begin{array}{l}n_{D}^{25} \\
1.438 \\
1.445 \\
1.450 \\
1.438 \\
1.436 \\
1.443 \\
1.455 \\
1.460\end{array}$ \\
\hline Total 102 to 110.5 & 30,080 & 26,700 & 2,785 & 595 & & & -- \\
\hline
\end{tabular}

\section{PRELIMINARY SEPARATION OF THE AROMATIC COMPONENTS FROM THE ADSORBED MATERIAL BY EXTRACTION}

In order to concentrate further the aromatic constituents, a trial portion of the adsorbed material was batch-extracted with liquid sulfur dioxide in four stages. The immiscible fraction, which consisted chiefly of nonaromatic hydrocarbons, was filtered through silica gel to remove the remaining portion of aromatic material. The combined sulfur dioxide layers, in turn, were batch-extracted with petroleum ether, in the manner described by Tausz [8], until they no longer contained nonaromatic constituents, except the solvent petroleum ether. After removing the sulfur dioxide, the low-boiling petroleum ether was separated from the aromatic material by fractional distillation. Data on the extraction are given in table 3.

Although the extraction effected a separation, in that substantially pure aromatic material was obtained, the data indicated that the 
procedure would not be satisfactory for treating small batches of oil, because of the relatively large portion of intermediate material. The method was therefore rejected in favor of a more convenient one based on azeotropic distillation.

TABLE 3.-Data indicating the degree of fractionation of the adsorbed material when subjected to batch-extraction with liquid sulfur dioxide and petroleum ether

\begin{tabular}{|c|c|c|c|}
\hline Fraction & Volume & $\begin{array}{l}\text { Refractive } \\
\text { index }\end{array}$ & $\begin{array}{l}\text { Estimated } \\
\text { mole per- } \\
\text { centage of } \\
\text { aromatics }^{a}\end{array}$ \\
\hline $\begin{array}{l}\text { Original } \\
\mathrm{SO}_{2} \text {-immiscible- } \\
\text { Petroleum ether extract }_{\mathrm{SO}_{2} \text { extract }}\end{array}$ & $\begin{array}{rr}m l & \\
450 \\
330 \\
b 60 \\
25\end{array}$ & \begin{tabular}{l|}
$n_{D}^{25}$ \\
1.438 \\
1.4275 \\
1.461 \\
1.4885
\end{tabular} & $\begin{array}{r}30 \\
15 \\
60 \\
\text { Nearly } 100^{6}\end{array}$ \\
\hline
\end{tabular}

a On basis of refractive index.

b Represents volume after a relatively large loss.

\section{DISTILLATION OF THE ADSORBED MATERIAL WITH ACETIC ACID}

It had been observed, while distilling a petroleum fraction (boiling at $136^{\circ} \mathrm{C}$ ) with an excess of acetic acid, that the hydrocarbons in the last distillate in which oil was present consisted chiefly of xylenes [9]. This behavior was attributed to the difference in boiling points of the azeotropic mixtures of the acid with the constituent paraffin, naphthene, and aromatic hydrocarbons [10]. To ascertain if azeotropic distillation would be practicable for separating the aromatic components from the gel-adsorbed material, a synthetic mixture of oil, containing $75 \mathrm{ml}$ of isopropylbenzene and $300 \mathrm{ml}$ of $n$-nonane, was distilled with 1,500 $\mathrm{ml}$ of acetic acid, through a Pyrex column having 30 plates equipped with bubbling caps. A reflux ratio of $20: 1$ and a distilling rate of $40 \mathrm{ml}$ an hour were maintained. After measuring their boiling points with a calibrated mercurial thermometer in a Cottrell boiler, the $100-\mathrm{ml}$ fractions were diluted with 4 volumes of water to separate the oil. The oil was then washed and its aromatic content determined by refractive index. Experimental data for the distillation are given in table 4.

From this experiment, it was observed that the minimum boiling point of the fractions containing $n$-nonane and acetic acid was $112.6^{\circ}$ to $112.7^{\circ} \mathrm{C}$; of those containing only isopropylbenzene and acetic acid, $116.7^{\circ}$ to $116.9^{\circ} \mathrm{C}$. The acetic acid boiled at $117.8^{\circ} \mathrm{C}$. The first seven fractions contained most of the $n$-nonane, and consisted of two layers at $25^{\circ} \mathrm{C}$. The eighth fraction, which contained 1 part of isopropylbenzene to 9 parts of $n$-nonane, was homogeneous at $25^{\circ} \mathrm{C}$ but formed two layers when cooled to $22^{\circ} \mathrm{C}$. The remaining fractions, which contained the isopropylbenzene and butlittle $n$-nonane, were homogeneous and remained so on cooling until crystals of acetic acid appeared. The fractions in which the $n$-nonane was concentrated contained about 1 volume of oil in 3 volumes of distillate. Those in which isopropylbenzene was concentrated contained 1 volume of oil in 6 volumes of distillate, and, at $25^{\circ} \mathrm{C}$, had specific gravities of 1.00 or slightly greater. Of the $n$-nonane, about 
TABLE 4.-Experimental data from the distillation $(760 \mathrm{~mm} \mathrm{Hg})$ of a mixture containing $75 \mathrm{ml}$ of isopropylbenzene and $300 \mathrm{ml}$ of $n$-nonane with excess acetic acid

\begin{tabular}{|c|c|c|c|c|c|c|}
\hline $\begin{array}{l}\text { Fraction } \\
\text { number }\end{array}$ & $\begin{array}{l}\text { Volume of } \\
\text { distillate }\end{array}$ & $\begin{array}{l}\text { Boiling } \\
\text { point of } \\
\text { "azeo-" } \\
\text { tropic" } \\
\text { distillate } a\end{array}$ & State at $25^{\circ} \mathrm{C}$ & Volume of oil & $\begin{array}{l}\text { Refractive } \\
\text { index of oil }\end{array}$ & $\begin{array}{l}\text { Total vol- } \\
\text { ume of oil } \\
\text { recovered }\end{array}$ \\
\hline $\begin{array}{l}1 \\
2 \\
3 \\
4 \\
4 \\
5\end{array}$ & $\begin{array}{l}m l \\
108 \\
107 \\
108 \\
120 \\
107\end{array}$ & $\begin{array}{l}{ }^{\circ} \mathrm{C} \\
112.6 \\
112.7\end{array}$ & 2 layers & $\begin{array}{c}\quad m l \\
30 \ldots \\
34 \\
433 \\
39\end{array}$ & $\begin{array}{l}n_{D}^{25} \\
1.4040 \\
1.4037_{5} \\
1.4037 \\
1.4036_{5} \\
1.4036\end{array}$ & $\begin{array}{lr}m l & \\
& 30 \\
& 64 \\
& 107 \\
& 150 \\
& 189\end{array}$ \\
\hline $\begin{array}{l}6 \\
7 \\
9 \\
90^{b}\end{array}$ & $\begin{array}{l}105 \\
102 \\
100 \\
102 \\
175\end{array}$ & $\begin{array}{l}113.1 \\
113.3 \\
116.7\end{array}$ & Homogeneous & $\begin{array}{l}37 \\
33 \\
38 \\
17.5 \\
29\end{array}$ & $\begin{array}{l}\text { 1. } 4036 \\
\text { 1. } 4038_{5} \\
\text { 1. } 4107 \\
\text { 1. } 4816 \\
1.4884\end{array}$ & $\begin{array}{l}226 \\
259 \\
297 \\
315 \\
344\end{array}$ \\
\hline 11 & $\begin{array}{l}110 \\
102 \\
102\end{array}$ & $\begin{array}{l}116.9 \\
117.5 \\
117.8\end{array}$ & 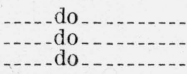 & $\begin{array}{l}18 \\
4.5 \\
\text { Emulsion only }\end{array}$ & $\begin{array}{l}\text { 1. } 4884 \\
\text { 1. } 4884\end{array}$ & $\begin{array}{l}362 \\
367\end{array}$ \\
\hline Column & $\begin{array}{l}98 \\
78\end{array}$ & $\begin{array}{l}117.9 \\
117.8\end{array}$ & _._. do & _._. do__._. & & \\
\hline Pot residue.. & 280 & & Contained sludge & _._. do do & & \\
\hline
\end{tabular}

${ }^{a}$ Boiling point at $760 \mathrm{~mm} \mathrm{Hg}$; relative only.

$\checkmark$ Distillation interrupted after removing this fraction.

99 percent was recovered by diluting the acid solution with water, but of the isopropylbenzene, 5 percent was held in the form of stable emulsions when the fractions containing it were diluted. However, the oil in the emulsions could be recovered readily by distillation with steam.

Since distillation with acetic acid effected a sharp separation of the components in the synthetic mixture, this method was used to obtain a further separation of the gel-adsorbed material, as well as to remove the aromatic constituents from the petroleum fractions which boiled between $154^{\circ}$ and $162^{\circ} \mathrm{C}[11] .^{7}$

Before applying the method to the gel-adsorbed material, one other experimental distillation was made with a mixture of the acid and a portion of the filtrate from the gel treatment, which boiled between $108.5^{\circ}$ and $109^{\circ} \mathrm{C}$. This was done in order to observe the azeotropic behavior of the naphthenes present. It was found from this experiment, that the fractions of acid distillate containing the constituent paraffins and naphthenes boiled within the range $112.4^{\circ}$ to $113.4^{\circ} \mathrm{C}$. Each fraction, when cooled, changed from a homogeneous state into two liquid phases, at temperatures ranging from $29^{\circ} \mathrm{C}$ for the initial ones to $17^{\circ} \mathrm{C}$ for the end ones. Those in which naphthenes were concentrated were homogeneous at $25^{\circ} \mathrm{C}$, had specific gravities ranging from 0.925 to 0.930 , and contained about $35 \mathrm{ml}$ of oil in 100 $\mathrm{ml}$ of solution.

As a result of this added information, the gel-adsorbed material described in table 2 was distilled with acetic acid. Each fraction of adsorbed material constituted the bulk of the oil distilled at one time. The quantity of acid used was $500 \mathrm{ml}$ in excess of the amount required to distil the oil if the latter were assumed to be entirely

\footnotetext{
${ }^{7}$ Concurrently, a study was made by S. T. Schicktanz of the azeotropism exhibited by a number of aromatic hydrocarbons, as well as paraffinic and naphthenic hydrocarbons, with acetic acid [12].
} 
naphthenic. This practice permitted all of the oil from any one fraction to be treated at a time. The amount of acid used was not sufficient, however, to distil all of the aromatic material, since for this purpose a much greater proportion of acid is required. With this exception the procedure for the systematic distillation was as described for the test experiment. Fractions were grouped according to the temperatures at which they separated into two layers on cooling, or according to their specific gravities, ${ }^{8}$ those containing only nonaromatic material in one group, and those containing aromatic compounds in another. The oil was then recovered by washing out the acid. Intermediate fractions were added to the next distillation. The still residue, which contained all impurities of the oil, besides some aromatic material, was mixed with water and distilled with steam in order to recover the aromatic constituents from the resulting stable emulsion. Most of the oil from the steam distillate was composed of aromatic compounds, but the last few percent, which was difficult to distil, had properties similar to those of kerosene. The gum remained in the distilling flask. Table 5 gives the experimental data for a typical distillation.

TABLE 5.-Experimental daia from the acetic acid distillation $(760 \mathrm{~mm} \mathrm{Hg})$ of the gel-adsorbed material from the petroleum fraction boiling between $103^{\circ}$ and $106^{\circ}$ $\mathrm{C}$ at $215 \mathrm{~mm} \mathrm{Hg}$

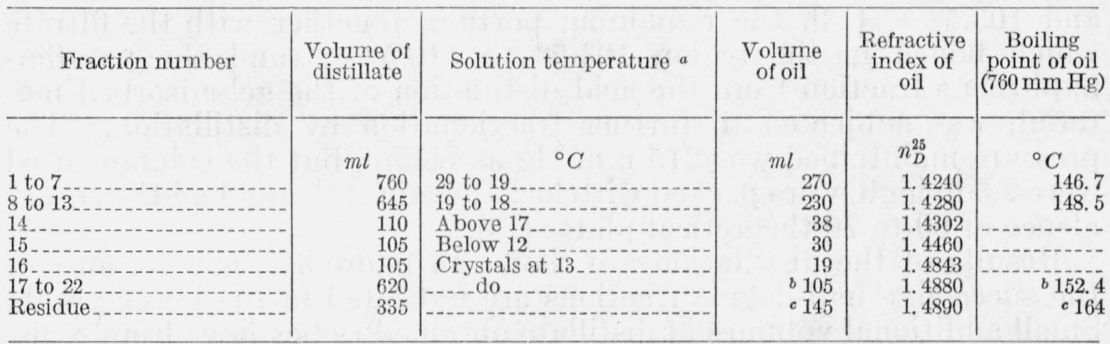

a Temperature at which the fraction, when cooled, changed from a completely miscible state into two liquid phases. See text.

$b$ Isopropylbenzene concentrate.

This fraction was obtained by steam distillation. A final fraction of $10 \mathrm{ml}$ was obtained by exhaustive distillation, which had an index of 1.4995 and boiled above $200^{\circ} \mathrm{C}$.

The properties of the fractions of aromatic material, obtained from the distillation with acetic acid, are given in table 6 . The boilingpoint data (column 4) indicate that most of the isopropylbenzene, $\mathrm{bp}_{760}, 152.4^{\circ} \mathrm{C}$, was present in the distillate boiling between $102^{\circ}$ and $108^{\circ} \mathrm{C}$ at $215 \mathrm{~mm} \mathrm{Hg}$. This fact indicates that, under the given conditions, isopropylbenzene distilled below $n$-nonane, $\mathrm{bp}_{760}, 150.7^{\circ} \mathrm{C}$, which accumulated in the fraction $108^{\circ}$ to $109^{\circ} \mathrm{C} .{ }^{9}$

8 Temperatures at which the fractions containing nonaromatic material separated into 2 layers ranged from about $30^{\circ} \mathrm{C}$ down to $17^{\circ} \mathrm{C}$. Their specific gravities varied between 0.925 and 0.940 , at $25^{\circ} \mathrm{C}$. The fractions containing aromatic material, however, were homogeneous at much lower temperatures and formed acetic acid crystals when sufficiently cooled. Their specific gravities were always near 1.00 and not less than 0.99 .

9 The fact that, upon fractionation of petroleum, the aromatic constituents accumulate in the distillate boiling below their boiling points has often been observed and is now generally accepted. Formerly, Sidney Young pointed this out in the case of toluene, J. Chem. Soc. 73, 918 (1898). That the phenomenon holds for aromatic hydrocarbons in general has been observed by members of this project, BS J. Research 6, 363 (1931) RP 280; 9, 711 (1932) RP 501, and by Tongberg, Fenske, and Sweeney, Ind. Eng. Chem. 30, 166 (1938). 
TABLE 6.-Volumes and properties of aromatic material recovered from the geladsorbed portion of the petroleum distillate by distillation with acetic acid

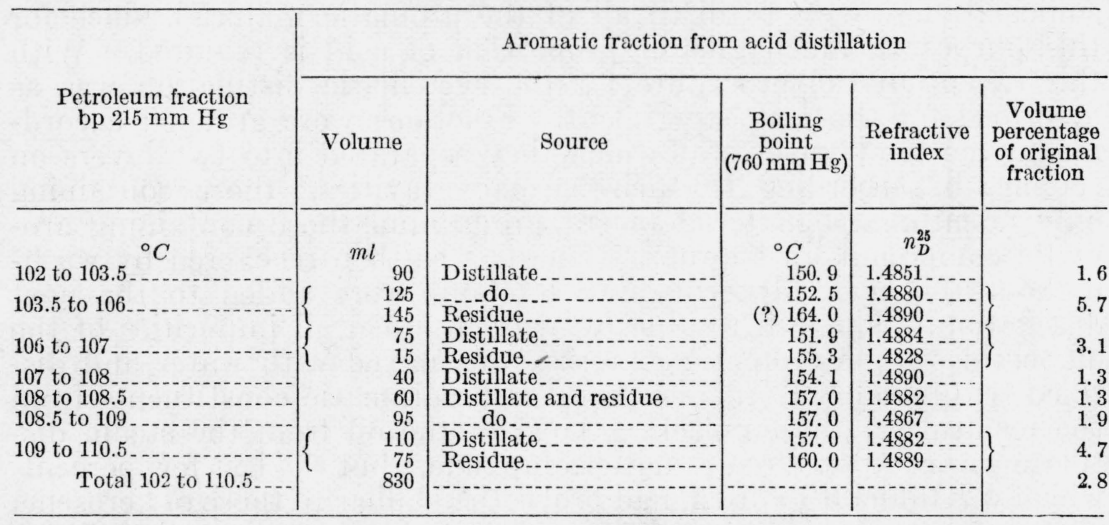

\section{FURTHER FRACTIONATION AND ANALYSIS OF THE MATERIAL FILTERED THROUGH SILICA GEL}

After the removal of $900 \mathrm{ml}$ of 3-methyloctane from the material which was filtered through silica gel and which boiled between $102^{\circ}$ and $103.5^{\circ} \mathrm{C}$ [13], the remaining portion, together with the filtrate which boiled in the region $103.5^{\circ}$ to $110.5^{\circ} \mathrm{C}$, and the paraffinnaphthene fraction from the acid distillation of the gel-adsorbed material, was subjected to further fractionation by distillation. The pressure maintained was $215 \mathrm{~mm} \mathrm{Hg}$ as before, but the columns used were $2.5 \mathrm{~m}$ high, were packed with locket chain [14], and had the equivalence of 60 to 70 theoretical plates [15].

Results of the distillation are shown in figure 3 . The volumes of the successive half-degree fractions are indicated in the lower graph. Small additional volumes of distillate obtained as headings from redistillation of that portion of the petroleum which boiled above $110.5^{\circ} \mathrm{C}$ [11] are denoted by the stippled areas. The lower curve in the figure gives the normal boiling point of each of the fractions distilled at 215 $\mathrm{mm} \mathrm{Hg}$. It is to be compared with the broken line just below it (" $\mathrm{bp} \mathrm{p}_{730}$ of paraffins") which passes through the normal boiling point of 3 methyloctane, $144.2^{\circ} \mathrm{C}$, and that of $n$-nonane, $150.7^{\circ} \mathrm{C}$.

It is apparent that a petroleum fraction, having the same boiling point at $215 \mathrm{~mm} \mathrm{Hg}$ as a given mixture of the paraffins, has a higher normal boiling point than the mixture. The difference is attributed to the presence of naphthenes in the petroleum, these compounds exhibiting a greater change in boiling point with pressure than the paraffins. A wide space between the curve and broken line shows that the petroleum fractions, boiling in the region indicated, consist chiefly of naphthenes. Where the curve and line converge, a predominance of paraffin hydrocarbons is indicated. The refractive index curve at the top of the figure shows clearly that the distillate in the region $103^{\circ}$ to $107^{\circ} \mathrm{C}$ is predominantly naphthenic, the indications being that two or more compounds of this nature are present. Other evidence indicates that the lower-boiling one has a normal boiling point between $145^{\circ}$ and $147^{\circ} \mathrm{C}$. The low value of 1.414 for the refractive index of the 8 -liter fraction boiling between $108.5^{\circ}$ and $109^{\circ} \mathrm{C}$ 


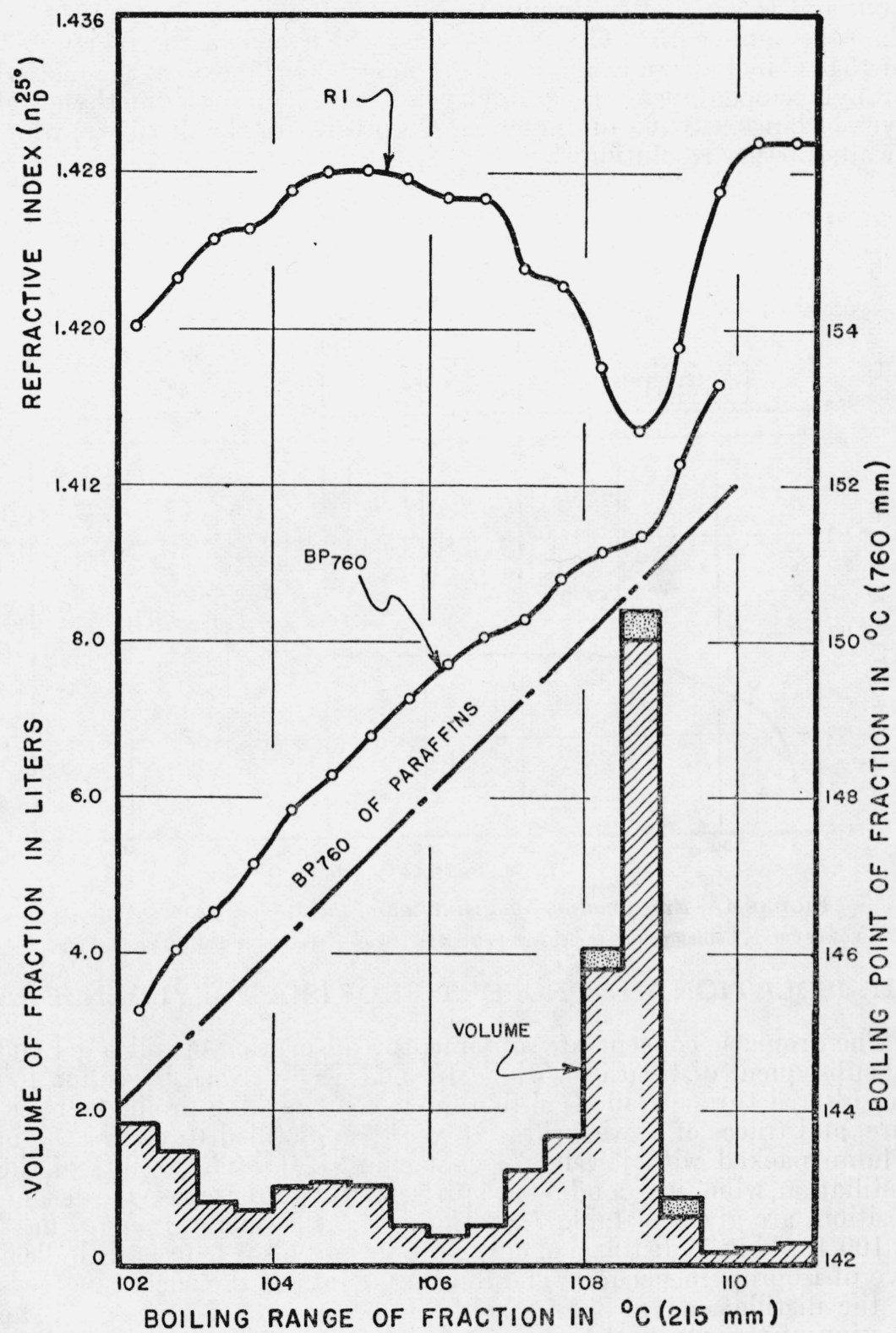

FIGURE 3.-Volumes, boiling points, and refractive indices of aromatic-free petroleum fractions after removing $n$-nonane and redistilling at $215 \mathrm{~mm} \mathrm{Hg}$.

The graph at the bottom shows the volume distribution with respect to boiling range of the material at $215 \mathrm{~mm} \mathrm{Hg}$. Lower curve, normal boiling points of successive half-degree cuts; upper curve, refractive indices. For significance of the broken line below the boiling-point curve, see text. 
is attributed chiefly to the presence of $n$-nonane, left from its fractionation, and to some of two naphthenes, one of which boils near $150^{\circ} \mathrm{C}$, the other above $153^{\circ} \mathrm{C}$. Naphthenes which boil in the region $145^{\circ}$ to $154^{\circ} \mathrm{C}$ include an isomeric 1,2,3-trimethylcyclohexane, the methylpropylcyclopentanes, the propylcyclohexanes, and the methylethylcyclohexanes. Some of these may be present in the distillate, which awaits further resolution. ${ }^{10}$

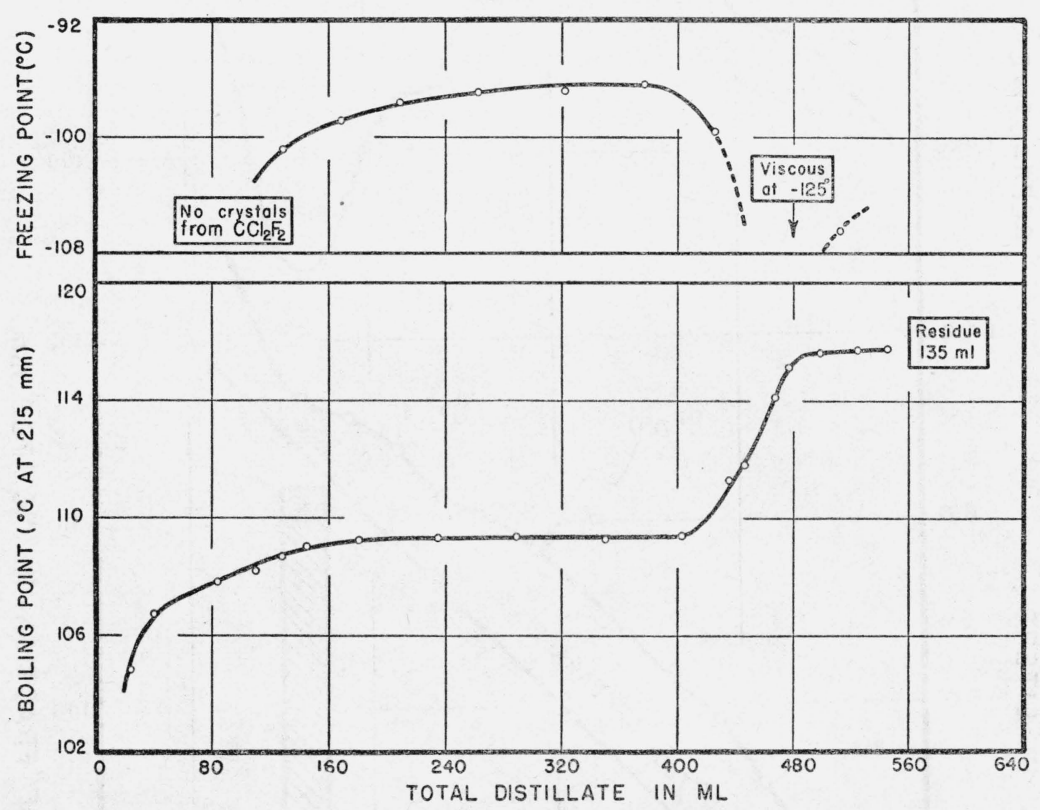

Figure 4.-Fractionation by distillation of the aromatic concentrate.

Lower curve, boiling points; upper curve, freezing points of successive distillation fractions.

\section{ISOLATION AND PROPERTIES OF ISOPROPYLBENZENE}

The aromatic concentrate, obtained by adsorption on silica gel and by subsequent distillation with acetic acid, as described in section IV, was filtered through silica gel to remove condensation products, moisture, and traces of acetic acid. It was then distilled through a $2.5-\mathrm{m}$ column packed with jewelers' locket chain [14]. The results of the distillation, which was conducted at $215-\mathrm{mm} \mathrm{Hg}$ pressure to avoid decomposition, are given in table 7 and figure 4. The boiling point "flat" at $109.4^{\circ} \mathrm{C}$ in the distillation curve (lower graph) of figure 4 is indicative of isopropylbenzene. The freezing points of the successive cuts of the distillation are shown in the upper graph of figure 4 . The fraction of the constant-boiling material (No. 11) having the highest freezing point, $-96.5^{\circ} \mathrm{C}$, was set aside as the best fraction of iso-

10 Tongberg, Fenske, and Sweeney have briefly discussed the composition of the distillate, boiling in the region $145^{\circ}$ to $155^{\circ} \mathrm{C}$, of a number of closely fractionated gasolines, and have reached conclusions similar to ours regarding its naphthenic nature [16]. 
propylbenzene. An effort was made to obtain an additional quantity of the compound, equal in purity to the "best by distillation", by crystallizing the less pure fractions from dichlorodifluoromethane ("Freon-12"), but the attempt was not successful because of the limited amount of material.

The cooling curve of the best fraction obtained by distillation is compared with that of a synthetic sample of isopropylbenzene ${ }^{11}$ in figure 5. The small temperature ranges in which the samples froze indicate a relatively high degree of purity.

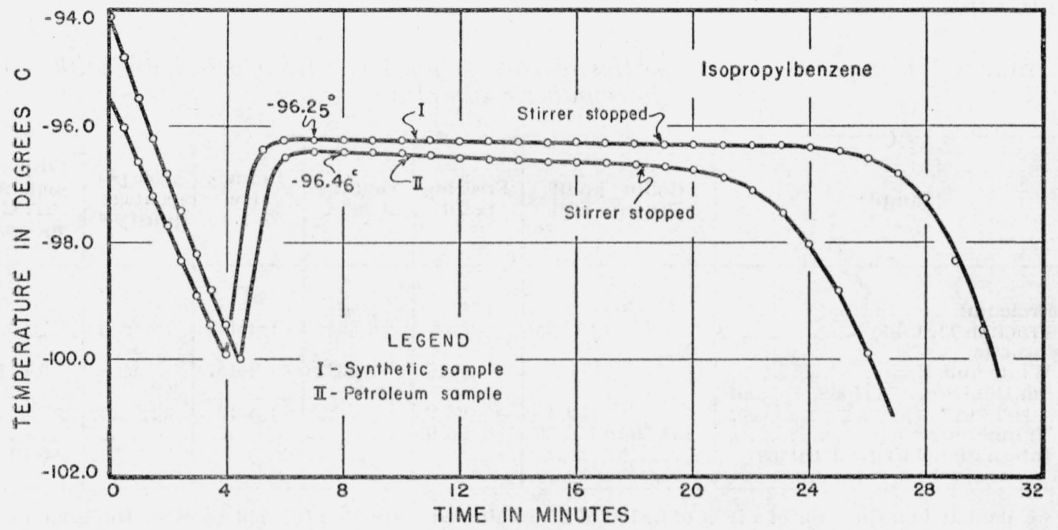

Figure 5.-Time-temperature cooling curves of samples of isopropylbenzene.

TABLE 7.-Results of the distillation of the aromatic concentrate

\begin{tabular}{|c|c|c|c|c|c|}
\hline \multirow{2}{*}{ Fraction number } & \multicolumn{2}{|c|}{ Volume } & \multirow{2}{*}{$\begin{array}{c}\text { Boiling } \\
\text { point }{ }^{a} \\
(215 \mathrm{mmHg})\end{array}$} & \multirow{2}{*}{$\begin{array}{l}\text { Refractive } \\
\text { index }^{a}\end{array}$} & \multirow{2}{*}{$\begin{array}{l}\text { Freezing } \\
\text { point } b\end{array}$} \\
\hline & Fraction & Total & & & \\
\hline 6 & $\begin{array}{cc}m l & \\
24 \\
16 \\
44 \\
26 \\
18 \\
17\end{array}$ & $\begin{aligned} & m l \\
& 24 \\
& 40 \\
& 84 \\
& 110 \\
& 128 \\
& 145\end{aligned}$ & $\begin{array}{l}{ }^{\circ} C \\
104.8 \\
106.7 \\
107.8 \\
108.2 \\
108.7 \\
109.0\end{array}$ & $\begin{array}{l}n_{D}^{25} \\
1.4809 \\
1.4855 \\
1.4877 \\
1.4884 \\
1.4885 \\
1.4887\end{array}$ & $\begin{array}{l}{ }^{\circ} \mathrm{C} \\
(c) \\
-100.9\end{array}$ \\
\hline 10 & $\begin{array}{l}36 \\
54 \\
54 \\
61 \\
53\end{array}$ & $\begin{array}{l}181 \\
235 \\
289 \\
350 \\
403\end{array}$ & $\begin{array}{l}\text { 109. } \\
\text { 109. } \\
\text { 109. } \\
\text { 109. } \\
109.4\end{array}$ & $\begin{array}{l}\text { 1. } 4888 \\
\text { 1. } 4889 \\
1.4889 \\
1.4889 \\
1.4892\end{array}$ & $\begin{array}{l}-98.9 \\
-97.7 \\
-97.0 \\
-96.9 \\
-96.5\end{array}$ \\
\hline $\begin{array}{l}12 \\
13 \\
14 \\
16\end{array}$ & $\begin{array}{l}32 \\
11 \\
12 \\
19 \\
21\end{array}$ & $\begin{array}{l}435 \\
446 \\
458 \\
477 \\
498\end{array}$ & $\begin{array}{l}111.3 \\
111.8 \\
114.1 \\
115.1 \\
115.6\end{array}$ & $\begin{array}{l}\text { 1. } 4892 \\
\text { 1. } 4892 \\
\text { 1. } 4894 \\
\text { 1. } 4896 \\
\text { 1. } 4897\end{array}$ & $\begin{array}{l}-99.7 \\
\text { (d) }\end{array}$ \\
\hline 17 & $\begin{array}{l}26 \\
20\end{array}$ & $\begin{array}{l}524 \\
544\end{array}$ & $\begin{array}{l}115.7 \\
115.7\end{array}$ & $\begin{array}{l}\text { 1. } 4898 \\
\text { 1. } 4898\end{array}$ & -166.5 \\
\hline $\mathrm{R}$ & 135 & 679 & & 1. 4918 & \\
\hline
\end{tabular}

a Relative only.

${ }^{b}$ Initial observed freezing point.

c No crystals from dichlorodifluoromethane (see text).

$d$ Viscous at $-125^{\circ} \mathrm{C}$.

11 Crude synthetic isopropylbenzene was obtained from Prof. E. E. Reid of The Johns Hopkins University and fractionated in a still having a 5 -m spiral column, which was coated with carborundum and equipped with a vacuum jacket and reflux regulator. From the fractions having constant-boiling points and refractive indices, those with nearly the same freezing point were combined and recrystallized from dichlorodifluoromethane to produce the "best" synthetic fraction. 
Other properties of the two samples are compared in table 8 with those reported for the compound in the literature. The excellent agreement is regarded as conclusive identification of the isopropylbenzene isolated from petroleum.

One other point concerning the distillation of the aromatic concentrate should be noted. The fact that the material in the boilingpoint plateau, at $115.7^{\circ} \mathrm{C}$, of the distillation curve (fig. 4) had freezing points, while fractions between $109.4^{\circ}$ and $115.7^{\circ} \mathrm{C}$ did not, is strong evidence for the presence of another compound, probably $n$-propylbenzene.

TABLE 8.-Comparison of properties of isopropylbenzene from petroleum with those for synthetic samples

\begin{tabular}{|c|c|c|c|c|c|c|}
\hline Sample & $\begin{array}{l}\text { Boiling point } \\
(760 \mathrm{~mm} \mathrm{Hg})\end{array}$ & $\begin{array}{c}\text { Freezing } \\
\text { point }\end{array}$ & $\begin{array}{l}\text { Density } \\
\text { at } 20^{\circ} \mathrm{C}\end{array}$ & $\begin{array}{c}\text { Refrac- } \\
\text { tive } \\
\text { index }\end{array}$ & $\begin{array}{l}\text { Mole per- } \\
\text { centage } \\
\text { purity }{ }^{a}\end{array}$ & $\begin{array}{c}\text { Disper- } \\
\text { sion at } \\
25^{\circ} \mathrm{C} \\
n_{F}-n_{C}\end{array}$ \\
\hline $\begin{array}{l}\text { Petroleum: } \\
\text { Fraction } 11 \text {, table } 7 .\end{array}$ & ${ }^{\circ} C_{d}{ }_{152.39}$ & $\begin{array}{c}{ }^{\circ} \mathrm{C} \\
-96.4_{6}\end{array}$ & $\begin{array}{l}g / m l \\
{ }_{0} \\
0.8634\end{array}$ & $\begin{array}{c}n_{D}^{20} \\
i 1.49142\end{array}$ & 98.4 & \\
\hline $\begin{array}{l}\text { Synthetic: } \\
\text { White and Rose.... }\end{array}$ & - $152.3_{8}$ & $f-96.2_{5}$ & h. 8633 & i 1.49157 & 99.8 & $k 0.0145$ \\
\hline $\begin{array}{l}\text { Smittenberg, Hoog, and } \\
\text { Henkes } b\end{array}$ & 102.08 & $0-96.2$ & & 1.4912 & & \\
\hline Timmermans $c_{-}$ & 152.50 to 152.55 & -96.9 & & & & \\
\hline International Critical Tables $i_{\ldots} \ldots$ & & & & & & 0.01453 \\
\hline
\end{tabular}

a Calculated on the basis of a heat of fusion of $2.1 \mathrm{Kcal} / \mathrm{mole}$, estimated by analogy with those for other aromatic hydrocarbons.

b J. Am. Chem. Soc. 60, 18 (1938).

c Bul. soc. chim. Belg. 36, 503 (1927).

$d \pm 0.03^{\circ} \mathrm{C}$. Determined by E. R. Smith of the Physical Chemistry Section of this Bureau in a standard Swietoslawski ebulliometer. $d t / d p=0.0507 \pm 0.002^{\circ} \mathrm{C} / \mathrm{mm}$.

- Determined in a Cottrell boiling-point apparatus relative to the petroleum sample.

$f$ Initial observed point using a spiral-coil platinum resistance thermometer of $25 \mathrm{ohms.} \mathrm{Extrapolated}$ initial freezing point, $-96.2_{2}^{\circ} \mathrm{C}$. Freezing point for 100.0 mole-percent isopropylbenzene, $-96.10^{\circ} \mathrm{C}$, estimated from the freezing-curve. See W. P. White, J. Phys. Chem. 24, 393 (1920).

- Melting point: $-96.1^{\circ} \mathrm{C}$.

$h$ Determined by the Division of Weights and Measures of this Bureau. $\Delta d / \Delta t=0.00085 /{ }^{\circ} \mathrm{C}\left(20^{\circ}\right.$ to $\left.25^{\circ} \mathrm{C}\right)$.

\pm 0.00005 . Determined on a calibrated Abbe refractometer (Valentine design).

$i$, 47 (MeGraw-Hill Book Co. Inc. N. Y., 1930).

${ }^{k}$ Value obtained from readings on the compensater drum of an Abbe refractometer (Spencer Lens Co.) and the tables furnished with the instrument.

${ }^{l}$ Value obtained from data on $n_{F}$ and $n_{C}$ at $16.8^{\circ} \mathrm{C}$ by assuming the specific dispersion to be constant.

\section{CONTENT OF ISOPROPYLBENZENE IN THE PETROLEUM}

Isopropylbenzene is present to only a small extent in the Oklahoma petroleum under investigation. Its amount by volume is estimated to be about 0.03 of the amount of the previously isolated $n$-nonane [4]. On the basis of the earlier estimate of 1 percent for the content of $n$-nonane in the crude oil, isopropylbenzene constitutes roughly 0.03 percent of the original petroleum. A more nearly correct value will be assigned to the actual content of isopropylbenzene, and the other constituent hydrocarbons, when a summary [17] of the complete analysis of the naphtha fraction is made.

\section{REFERENCES}

[1] Warren de La Rue and Hugo Müller, Proc. Roy. Soc. (London) 8, 221 (1856).

[2] See citations in Engler-Höfer, Das Erdöl 1, 359 (Hirzel, Leipzig, 1913). See also, Mulany and Watson, J. Soc. Chem. Ind. 43, 310 T (1924); Tonberg, Fenske, and Nickels, Ind. Eng. Chem. 29, 70 (1937). 
[3] H. M. Mulany and E. R. Watson, J. Soc. Chem. Ind. 43, 310 T (1924).

[4] J. D. White and F. W. Rose, Jr., BS J. Research 7, 907 (1931) RP383.

[5] J. D. White and F. W. Rose, Jr., BS J. Research 9, 711 (1932) RP501.

[6] B. Tarasov, Azerbałdzhanskoe Neftyanoe Khoz. 1, No. 10, 47 (1926).

H. Hofmeir and H. Meiner, Z. angew. Chem. 46, 229 (1933).

Private communication from Dr. B. J. Mair, National Bur. Standards.

[7] B. J. Mair and J. D. White, J. Research NBS 15, 51 (1935) RP809.

[8] J. Tausz and A. Stüber, Z. angew. Chem. 32 I, 175 (1919).

[9] J. D. White and F. W. Rose, Jr., J. Research NBS 1\%, 946, footnote 7 (1936) RP955.

[10] M. Lecat, Int. Crit. Tables 3, 319 (McGraw-Hill Book Co. New York, N. Y., 1928).

S. T. Schicktanz, J. Research NBS 18, 129 (1937) RP967.

[11] F. W. Rose, Jr., and J. D. White, J. Research NBS 21, 167 (1938) RP1123.

[12] S. T. Schicktanz, unpublished.

[13] J. D. White and A. R. Glasgow, Jr., J. Research NBS 19, 423 (1937) RP1033.

[14] S. T. Schicktanz, BS J. Research 11, 89 (1933) RP579.

[15] A. R. Glasgow, Jr., and S. T. Schicktanz, J. Research NBS 19, 593 (1937) RP1049.

[16] C. O. Tongberg, M. R. Fenske, and W. J. Sweeney, Ind. Eng. Chem. 30, 166 (1938)

[17] R. T. Leslie and J. D. White, J. Research NBS 15, 218 (1935) RP824.

F. D. Rossini, Proc. Am. Pet. Inst. 18 (III), 36 (1937); Oil Gas J. 26, No. 26, 193 (1937).

Refiner Natural Gasoline Mfr. 16, 545-62 (1937).

Washington, January 13, 1938. 